International Journal of Pharmaceutics \& Pharmacology

Available Online: https://ijpp.edwiserinternational.com

\title{
How Kerala and Rajasthan Mitigated COVID-19: A Comparative Study
}

\author{
Yash Jain $^{1 *}$, Kanav Midha ${ }^{2}$ and Simran Marwah ${ }^{3}$ \\ ${ }^{1}$ IIHMR University, Jaipur \\ ${ }^{2}$ Jaypee Brothers Medical Publishers Pvt Ltd, Delhi \\ ${ }^{3}$ Amity University, Noida, India
}

Article info

Received 20 July 2020

Revised 12 August 2020

Available Online 15 August 2020

*Corresponding author: Yash Jain, IIHMR University, Jaipur, India; Email: Yashjain709@gmail.com

\begin{abstract}
All the countries of the world have been taking all the possible precautionary measures to combat COVID-19. In India, although there are many states which were affected by this flareup, the authors had taken only two states, i.e., Kerala and Rajasthan. Both the states did their best to combat this pandemic. Kerala was the first state to witness the first case in India on $30^{\text {th }}$ January 2020 whereas in Rajasthan, the first case was tested on $2^{\text {nd }}$ March 2020. After announcing this flareup as a pandemic by WHO, all the states did their best to break the chain of transmission, till date the recovery rate of India is $63.30 \%$, Kerala is $47 \%$, and Rajasthan is $73 \%$. The high rate of recovery and low rate of case fatality show the benefits of early lockdown and the precautionary measures taken by Government of India and State governments (Kerala and Rajasthan). This paper implies the comparative study of all the precautionary measures and situation of COVID-19 in the two states.
\end{abstract}

Keywords: Pandemic; COVID-19; Kerala; Rajasthan

\section{Introduction}

Kerala is the southern state of India, holding peculiar features of development among other Indian states since its inception; it is mainly regarded as 'Kerala Model of Development' [1]. Kerala model is based on improving health, education, and quality of life for people. The state has experienced a decrease in the birth rate, mortality rate, and decline in the rate of growth of the population [1]. While Rajasthan is the north-western side of India and largest state area-wise and seventh largest state by population. It covers mostly desert area which is known as the Thar desert. Both States experienced COVID-19 effects on their economy, transportation, education, and the like. COVID-19 stands for Coronavirus disease 2019. The first case of this disease was found in Wuhan, China, in 2019. The symptoms of this disease were different from person to person, but the most common symptoms are fever, dry cough, tiredness, and, in severe conditions, difficulty in breathing [2]. The other symptoms of the disease are aches and pain, sore throat, diarrhea, conjunctivitis, headache, loss of taste and smell, and a rash on skin, or discoloration of fingers or toes [2,3]. There is no vaccine available in the market till date. The only treatment for this disease is prevention because prevention is better than cure [4]. Prevention measures for the disease are to wear masks, follow social distancing, wash hands frequently for 20 seconds by soap or sanitizers $[2,3]$. In India, the highest recovery rate showed the high immunity power of the citizens. Let us take a glance on the timelines of the States to know about the precautionary measure taken by the government officials.

\section{States Timeline}

\section{Kerala}


Kerala identified the first case on $3^{\text {rd }}$ February 2020. K.K. Shailaja, Health Minister, released all the information to the state by the press conference to avoid misleading information [5]. To prevent the spread of infection, government announced that the school, universities, and cinemas will remain shut in the state till $31^{\text {st }}$ March 2020 [5]. Crowded places like sanctuaries, churches, social places, and political rallies would be avoided. Officials of Kerala set up the public hospital's beds into isolation wards [6]. After a person being confirmed positive, they made a travel route map of the person to identify the possible carrier of COVID19 in state and such patients were advised to put themselves into home quarantine and if needed any medical assistance, call the helpline number [6,7]. Government issued several advisories and guidelines for the basic health sanitation and social distancing norms to prevent the disease [6].

To avoid the false reports, they set up a media monitoring team to identify a false claim individual and punished them. They also created a platform in a regional language for the correct information about the individuals, prevention strategies, and travel history of the patients $[6,8]$. After confirming the three cases, Kerala government announced the state calamity and proposed the guidelines for quarantine. The central government proposed a quarantine time of 14 days, yet the Kerala government did not take any chance and made the isolating period for 28 days to be necessarily followed as a prudent measure [9]. A team was made with the Director of Health Services (DHS), additional DHS and MD and the state-run medical service to analyse the situation, enhance the testing, and spread awareness by posters and hoarding $[1,6]$. The team officers faced the issue of lack of mask and sanitizers, so they decided to produce those in the jails with the help of prisoners and to fulfil the requirement they contacted the government pharmaceutical industry $[1,6]$. Government setup their COVID-19 first laboratory at National Institute of Virology, Alappuzha in Kerala to avoid the delay in test reports. They also helped the people in home quarantine by providing them essential supplies [6]. The government proposed and implemented a series of actions from time to time. Strict screening at all the airports, ports, railway station, bus stands, and state borders was started [6]. A campaign to promote personal hygiene to cut down the spread of COVID19, called 'Break the chain' was initiated $[6,10]$. Politicians, sportspeople, celebrities, and many others accompanied to promote the campaign and they recorded videos promoting hand washing, personal hygiene, and spread them through their social media [10]. As a part of this, the government installed water taps at public spots with hand-washing facilities. Besides, DYFI has set up many handwashing centers in public places across the state. For providing psychological support to the families of suspected persons, 215 persons have been assigned across the state [6]. The government officials divided the states into 2 red zones, 9 orange zones, and 3 green zones. In Unlock 1 , the state decided to observe a complete lockdown on Sundays without any relaxations $[5,11,12]$.

\section{Rajasthan}

The first case in Rajasthan was first detected on $2^{\text {nd }}$ March 2020. Jaipur was the most affected city among the 31 cities of Rajasthan [13]. To prevent the spread of disease, Rajasthan government had imposed Section 144 in the state, in which no more than 5 persons were allowed to assemble. All the passengers entering the state at the airports and railway stations were checked for the symptoms and those showing the symptoms were advised home quarantine for 14 days. Rajasthan was the first state which announced total lockdown in state from $22^{\text {nd }}$ March to $31^{\text {st }}$ March [13]. People were not allowed to move on roads without any essential need. The state government declared free food supplies for 2 months for families under the National Food Security Act (NFSA) [13]. In the meantime, Rajendra Bhatt created a model for the state called as "Bhilwara Model" [14]. They tested all the citizens of the city within 7 days [14]. The timeline for Bhilwara model is briefed as follows.

\section{Bhatt's Model - The Method in The Madness}

March 21: Bhilwara had the highest number of cases in the state so all the manufacturing plants, businesses, and all the shops to be shut down and Section 144 to be imposed in the state. Screening performed at all the entries of the city [15].

March 22: Officials issued a notification of lockdown in the city; no private and public vehicles to be allowed on the roads. A request was made to hotels and resorts to give their space for healthcare crisis [15].

March 23: The guest houses were taken for isolation and quarantine which was accounted to about 6000 rooms with some of them having attached toilet. The nutritious food was given by Akshay Patra [15].

March 24 to 26: Hostels of instructive establishments taken over to build isolation centers. 5 emergency clinics taken over alongside staff, hardware, and clinical 
supplies. Suspected cases at focal point confined in government clinics. $24 * 7$ war room set up [15].

March 28 to 30: Those who have symptoms should be home quarantined and a 24-hour review requested. Home-to-home screening of $92 \%$ of the population of the city was done [15].

March 31: The cases stopped at 27. Be that as it may, organization fixes development considerably further till April $15^{\text {th }}$. The delivery of milk and other essential products was guaranteed door to door [15]. After implementing Bhilwara model, the state government declared financial help of 50 lakhs for government employees who died due to COVID-19 in serving their duties in hospitals, police, and sanitation workers on $11^{\text {th }}$ April. MHA issued guidelines and divided the state into three zones, i.e., red, green, and orange. Rajasthan has 8 red zones, 19 orange zones, and 6 green zones $[12,13]$. In Unlock 1, some relaxations were given to uplift the economy along with an increase in the testing rate of the state [13].

Table 1: Distribution of Cities in Three Zones ( $1^{\text {st }}$ May).

\begin{tabular}{|l|l|l|l|}
\hline States/ Zones & Red zone & Orange zone & Green zone \\
\hline Kerala [12] & Kannur, Kottayam & $\begin{array}{l}\text { Idukki, Kasaragod, Kollam, Kozhikode, Malap } \\
\text { puram, Palakkad, Pathanamthitta, Thiruvanant } \\
\text { hapuram, Alappuzha, Thrissur }\end{array}$ & $\begin{array}{l}\text { Ernakulam, Wa } \\
\text { yanad }\end{array}$ \\
\hline Rajasthan [12] & $\begin{array}{l}\text { Jaipur, Jodhpur, } \\
\text { Kota, Ajmer, } \\
\text { Bharatpur, Nagore, } \\
\text { Banswara, Jhalawar }\end{array}$ & $\begin{array}{l}\text { Tonk, Jaisalmer, Dausa, Jhunjhunu, } \\
\text { Canumangarh, Bhilwara, Sawaimadhopur, } \\
\text { Chittorgarh, Dungarpur, Udaipur, Dholpur, } \\
\text { Sikar, Alwar, Bikaner, Churu, Pali, Barmer, } \\
\text { Karauli, Rajsamand }\end{array}$ & $\begin{array}{l}\text { Bara, Bundi, } \\
\text { Ganganagar, } \\
\text { Jalore, Sirohi, } \\
\text { Pratapgarh }\end{array}$ \\
\hline
\end{tabular}

\section{Analysis}

Research Objective: To compare the COVID-19 situation in two states of India (Kerala and Rajasthan).

Research Question: What is the situation of COVID19 in Kerala and Rajasthan?

\section{Methodology}

\section{Data Collection: Secondary Sources}

Type of Research: Secondary Research

Study Design: Descriptive Study

Parameters: Case fatality rate, Recovery rate, Outcome ratio (death to recovered cases), and Recovery ratio (recovered to active cases)

Table 2: Parameters of two states.

\begin{tabular}{|c|c|c|}
\hline Parameters & Kerala & Rajasthan \\
\hline First case detected & 30th January & 2nd march \\
\hline Population & 3.48 crores & 6.89 crores \\
\hline Total cases (till $16^{\text {th }}$ July 2020) $[16,17]$ & 10,276 & 27,174 \\
\hline Active cases (till $16^{\text {th }}$ July 2020) $[16,17]$ & 5372 & 6666 \\
\hline Recovered cases $\left(16^{\text {th }}\right.$ July 2020) $[16,17]$ & 4862 & 19,970 \\
\hline Death (till $16^{\text {th }}$ July 2020$)[16,17]$ & 38 & 538 \\
\hline Case fatality rate (till $16^{\text {th }}$ July 2020$)$ & $0.37 \%$ & $7.98 \%$ \\
\hline Recovery rate (till $16^{\text {th }}$ July 2020) & $47.31 \%$ & $2.69 \%$ \\
\hline Outcome ratio (deaths to recovered cases) & $0.78 \%$ & $299.57 \%$ \\
\hline Recovery ratio (recovered to active cases) & $90.50 \%$ & 14 days \\
\hline Quarantine period (Initially) & 28 days & \\
\hline
\end{tabular}


Citation: Jain Y, Midha K, Marwah S. How Kerala and Rajasthan Mitigated COVID-19: A Comparative Study. Int J Pharm Pharmacol 2020; 4: 145. doi:10.31531/2581-3080.1000145

\begin{tabular}{|c|c|c|} 
Testing (till 16 $6^{\text {th }}$ July 2020), (Source: MOHFW) & $\begin{array}{c}472,271(13,445 \text { per } 1 \\
\text { million people) }\end{array}$ & $\begin{array}{c}11,51,952(14,909 \text { per } 1 \\
\text { million people) }\end{array}$ \\
\hline Social awareness campaign & $\begin{array}{c}\text { Break the chain campaign } \\
\text { Aware the society by } \\
\text { social media campaign } \\
\text { The government has } \\
\text { launched a mobile } \\
\text { application called GoK } \\
\text { Direct for users to get } \\
\text { information and updates } \\
\text { regarding the COVID-19 }\end{array}$ & $\begin{array}{c}\text { Aware the society by social } \\
\text { media }\end{array}$ \\
\begin{tabular}{c|c} 
Bhilwara model of COVID- \\
19
\end{tabular} \\
\hline Total testing laboratories (including RT-PCR, True & $25 \mathrm{G}$ & \\
Nat, CB NAAT) $[18,19]$ & $10 \mathrm{P}$ & $27 \mathrm{G}$ \\
\hline Total containment districts & 14 & $26 \mathrm{P}$ \\
\hline
\end{tabular}

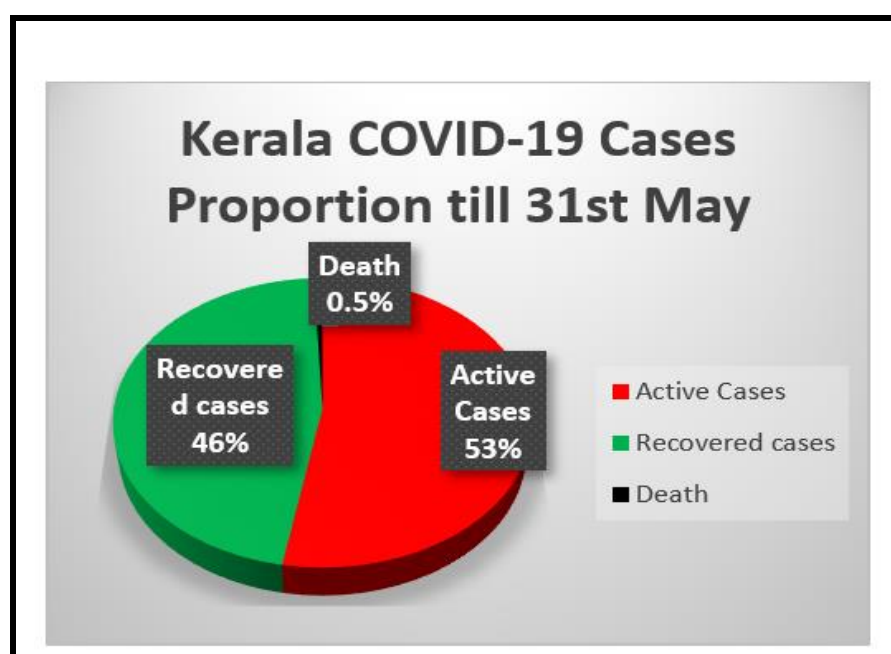

Graph 1: Proportion of cases till $31^{\text {st }}$ May in Kerala $[16,20]$.

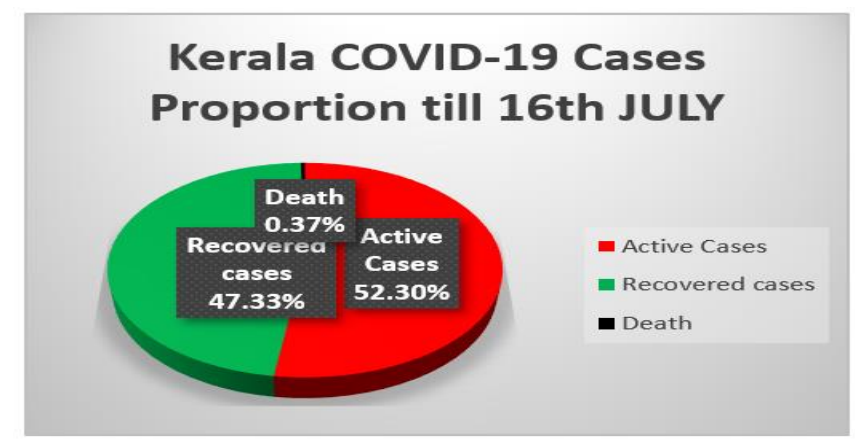

Graph 2: Proportion of cases till $16^{\text {th }}$ July in Kerala $[16,20]$.

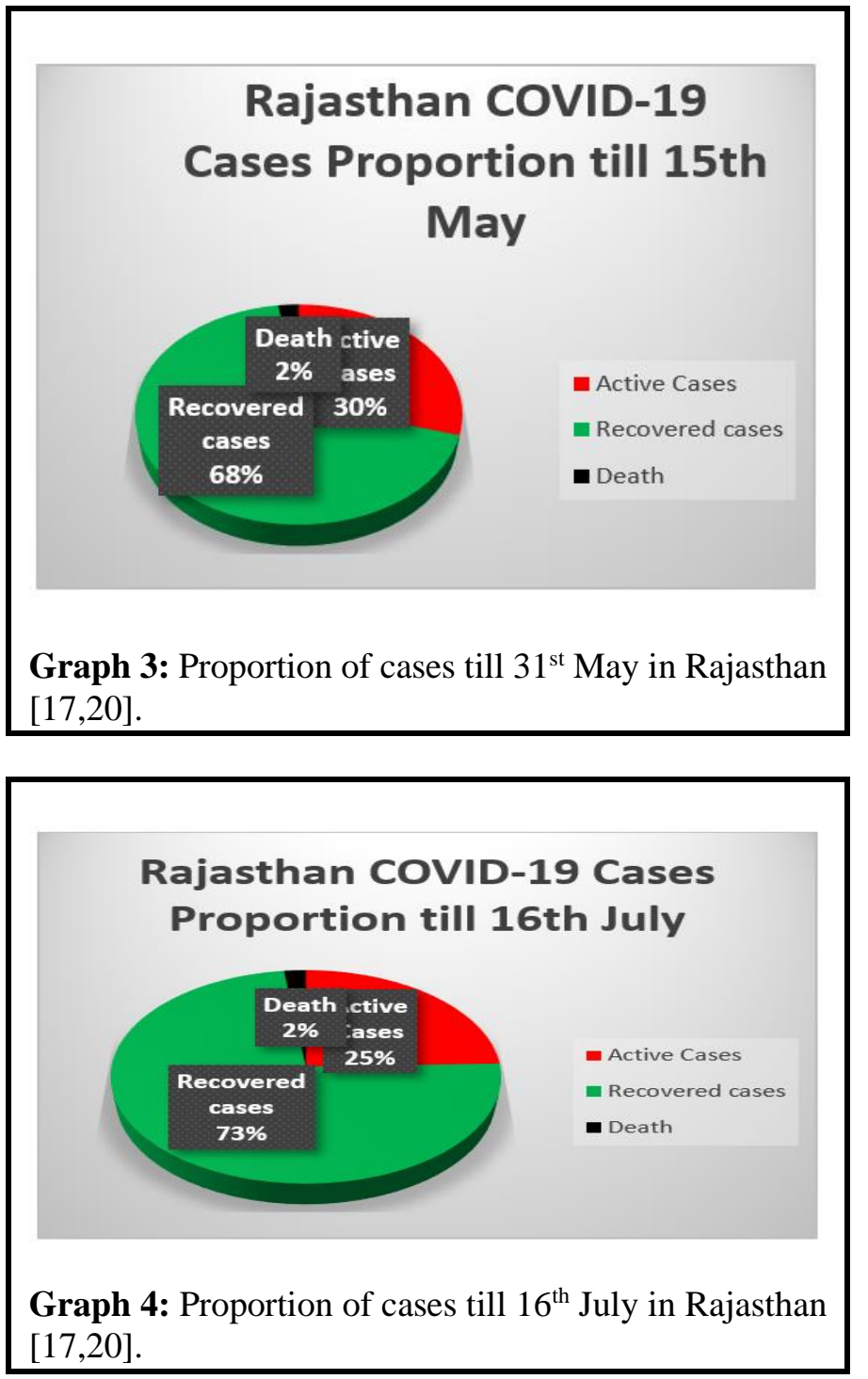

Interpretation: Graph 1 shows the Kerala proportionwise data till $31^{\text {st }}$ May, i.e., till 4th lockdown. It shows $46 \%$ recovery rate and $0.5 \%$ case fatality rate. Graph 2 
depicts the proportion-wise data of Kerala till $16^{\text {th }}$ July, i.e., Unlock 2 , which implies $47.33 \%$ recovery rate and $0.37 \%$ case fatality rate.

Interpretation: Graph 3 shows the Rajasthan proportion-wise data till $31^{\text {st }}$ May, i.e., till $4^{\text {th }}$ lockdown which implies $68 \%$ recovery rate and $2 \%$ case fatality rate. Graph 4 depicts the proportion-wise data of Rajasthan till $16^{\text {th }}$ July, i.e., Unlock 2 , which implies $73 \%$ recovery rate and $1.98 \%$ case fatality rate.

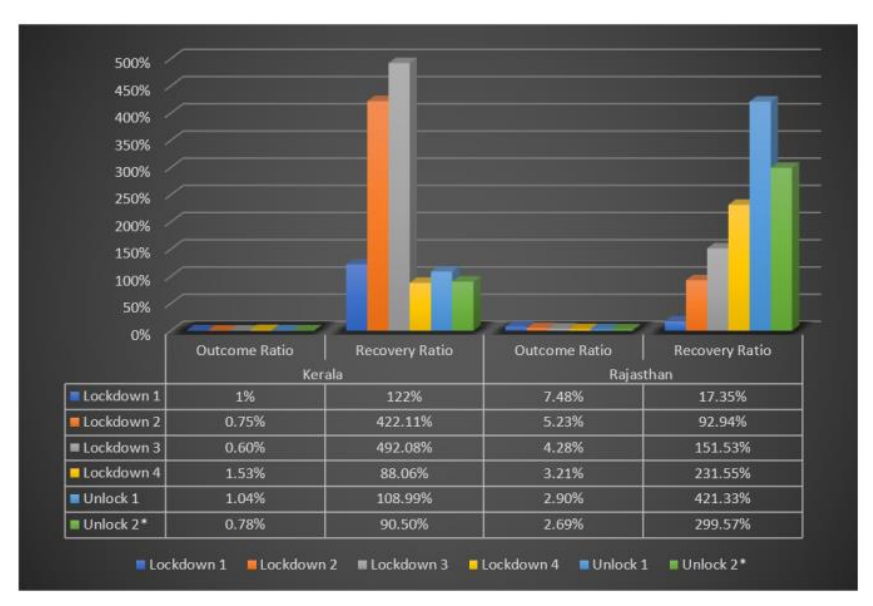

Graph 5: Comparing outcome ratio (OR) and recovery ratio of Kerala and Rajasthan in Lockdown 1, 2, 3, and 4 and Unlock 1 and Unlock 2 (*means till $16^{\text {th }}$ July). (Source: MOHFW)

Interpretation: Graph 5 depicts OR and RR in Kerala and Rajasthan in the period of lockdown and unlock till $16^{\text {th }}$ July 2020. In lockdown 1,2 , and 3, Kerala recovery ratio was about $122 \%, 422.11 \%$, and $492.08 \%$, and after that it dropped down to $88 \%$ in lockdown 4 , and then ultimately $90.5 \%$ till 16 th July. While Rajasthan had lower recovery rate initially; it gradually increased to $421.33 \%$ and then it dropped down to $299.57 \%$ in Unlock 2 (till $16^{\text {th }}$ July).

In India, total cases of COVID-19 are 10,05,637. Out of which, the active cases are $3,43,036$, the recovered cases are 6,36,602, and the deaths are 25,609 (Till $16^{\text {th }}$ July) $[20,21]$.

\section{Conclusion}

Both the states have tackled this pandemic in a very serious and strategic manner. Initially, Kerala was the state which had highest recovery rate in lockdowns 1 and 2 but at the end of lockdown 3 , there was a downfall in the recovery rate due to increasing number of cases of COVID-19 but the outcome ratio and case fatality rate of the state were less than 1 which had various reasons like low mortality rate, quality of care, high literacy rate, high immunity, strict precautionary actions, awareness campaign, and good hygienic practices. While Rajasthan mitigated this epidemic in such a way that it had the highest recovery rate of COVID-19 in India. Rajasthan had 73\% recovery rate till 16th July 2020 and $1.98 \%$ of fatality rate and Kerala had $47.33 \%$ recovery rate and $0.37 \%$ fatality rate while India had recovery rate of $63.30 \%$ and $2.54 \%$ case fatality rate $[22,23]$. Both the states have low case fatality rate in comparison to the whole country rates and Kerala has lower recovery rate in comparison to the country because of the increasing cases of COVID-19. In terms of RR and OR, India stands at $185.78 \%$ and $4.02 \%$ while Kerala at $90.50 \%$ and $0.78 \%$ and Rajasthan at $299.57 \%$ and $2.69 \%$ till $16^{\text {th }}$ July 2020. Rajasthan took all the precautionary measures on time, created awareness in the society, and increased the testing rate of the state and that is why it holds the first position in recovery rate of the country.

\section{Funding}

None declared.

\section{References}

1. Maneesh P, Alaoui, A. How Countries of South Mitigate COVID 19: Models of Morocco and Kerala, India. Elect Res J Social Sci Humanities 2020; 2: 16-28.

2. Ministry of Health and Family Welfare, Government of India. [Cited 2020 July 16]. Available from: https://www.mohfw.gov.in/

3. Coronavirus disease (COVID-19) Pandemic, Emergency; World Health Organisation. [Cited2020 July 16]. Available from: https://www.who.int/emergencies/diseases/novelcoronavirus-2019

4. Jahangir MA, Muheem A, Rizvi MF. Coronavirus (COVID-19): History, Current Knowledge and Pipeline Medications. Int J Pharm Pharmacol 2020; 4: 140.

5. Narasimhan TE. India's first coronavirus case: Kerala student in Wuhan tested positive. Business Standard India. Business Standard January 30,2020[Cited2020 July 16] Available at: https://www.business-standard.com/article/currentaffairs/india-s-first-coronavirus-case-keralastudent-in-wuhan-tested-positive-120013001782

6. Coronavirus Pandemic in Kerala 2020 Wikipedia. [Cited2020 July 16]. Available from: 
https://en.wikipedia.org/wiki/2020_coronavirus_pa ndemic_in_Kerala

7. Kerala Defeats Coronavirus: India's Three COVID19 Patients Successfully Recover. The Weather Channel. TWC India Edit Team. Weather Channel. (Cited2020 July 16) Available from: https://weather.com/en-IN/india/news/news/202002-14-kerala-defeats-coronavirus-indias-threeCOVID-19-patients-successfully

8. Kerala govt launches mobile app for users to track coronavirus updates. The News Minute News March 13, 2020 [Cited2020 July 16] Available From:https://www.thenewsminute.com/article/kera la-govt-launches-mobile-app-users-trackcoronavirus-updates-120104

9. Oommen CK. How an Indian state successfully fought and contained the deadly coronavirus. Quartz India. Quartz. February 142020 [Cited2020 July 16] Available from: https://qz.com/india/1802684/indias-keraladefeated-deadly-coronavirus-using-information/

10. Kerala govt launches break the chain initiative for personal hygiene. NDTV. March 17, 2020 [Cited2020 July 16] Available From: https://www.ndtv.com/kerala-news/keralalaunches-break-the-chain-campaign-to-combatcoronavirus-2196103

11. COVID-19 Kerala bulletin (Hotspots) Government of Kerala [Cited2020 July 16] Available at: https://dashboard.kerala.gov.in/hotspots.php.

12. Red, Orange, Green Zone district-wise list for coronavirus lockdown: Complete classification of areas in India" India Today [Cited2020 July 16] Available From: https://www.indiatoday.in/india/story/red-orangegreen-zones-full-current-update-list-districtsstates-india-coronavirus-1673358-2020-05-01

13. Coronavirus Pandemic in Rajasthan 2020 Wikipedia. [Cited2020 July 16]. Available from:https://en.wikipedia.org/wiki/2020_coronavir us_pandemic_in_Rajasthan

14. Bhilwara model: How this Rajasthan district brought COVID-19 under control by business standard special on coronavirus April 10, 2020
[Cited2020 July 16] Available from: https://www.business-standard.com/article/currentaffairs/bhilwara-model-how-this-rajasthan-districtbrought-COVID-19-under-control120041000286_1.html

15. Bhatt's Model of Madness of Bhilwara Infographics [Cited2020 July 16]. Available from: https://infogram.com/bhilwara-gfx-21hmr6gv9yn196nl

16. COVID-19 tracking dashboard Ministry of Health and Family Welfare, Government of Kerala [Cited2020 July 16] Available from: https://dashboard.kerala.gov.in/

17. COVID-19 Dashboard by Ministry of Health and Family Welfare, Government of Rajasthan [Cited2020 July 16]. Available from: "www.rajswasthya.nic.in

18. List of Private Laboratories to test COVID-19 by Indian council of medical research [Cited2020 July 16] Available at: https://www.icmr.gov.in/pdf/covid/labs/COVID_T esting_Labs_24052020.pdf

19. Total Operational (initiated independent testing) Laboratories reporting to ICMR [Cited2020 July 16] Available From: https://www.icmr.gov.in/pdf/covid/labs/COVID_T esting_Labs_24052020.pdf

20. COVID-19 Dashboard by Ministry of Health and Family Welfare, Government of India. [Cited2020 July 16]. Available from: www.covid19india.org

21. Coronavirus Pandemic in India 2020 Wikipedia. [Cited2020 July 16]. Available from: https://en.wikipedia.org/wiki/2020coronavirus_pan demic_in_India

22. COVID-19 Body Count: India's Low Mortality Rate and the Contrasting Pictures of Two States". News18. [Cited2020 July 16] Available From: https://www.news18.com/news/india/COVID-19body-count-indias-low-mortality-rate-and-thecontrasting-pictures-of-two-states-2578653.html

23. India Fights Corona COVID-19 by Government of India. 2020. [Cited2020 July 16]. Available from: https://www.mygov.in/COVID-19/

This manuscript was peer-reviewed

Mode of Review: Single-blinded

Academic Editor: Dr. MA Jahangir

Copyright: (C2020 Jain Y, et al. This article is distributed under the terms of the Creative Commons Attribution 4.0 International License (http://creativecommons.org/licenses/by/4.0/), which permits unrestricted use, distribution, and reproduction in any medium, provided you give appropriate credit to the original author(s) and the source, provide a link to the Creative Commons license, and indicate if changes were made. 